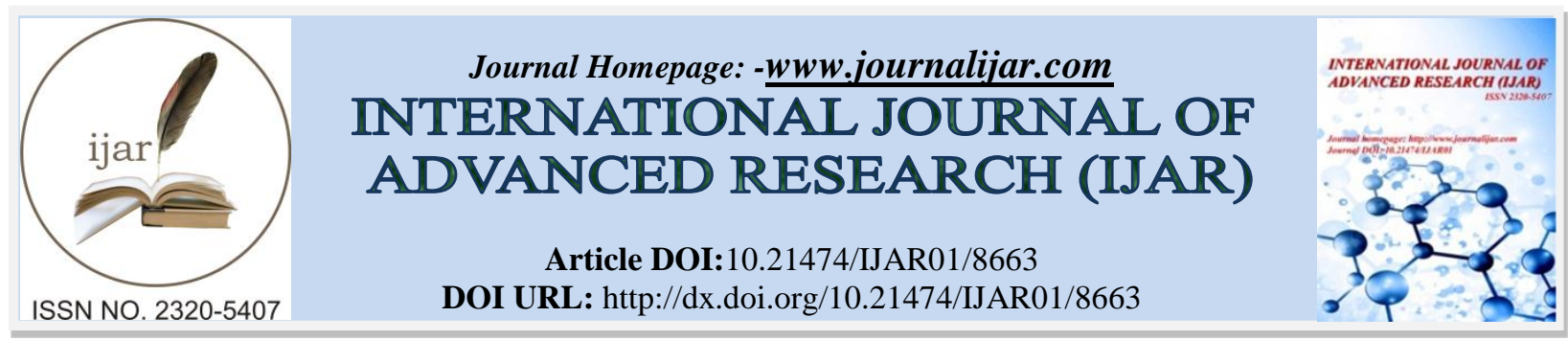

RESEARCH ARTICLE

\title{
ATTITUDE AND CURRENT EXPERIENCE OF DENTISTS ABOUT NON-SURGICAL RETREATMENT OF ENDODONTICALLY TREATED TEETH.
}

\author{
Mohammad I. Albakheet ${ }^{1}$, Mohammed G. Alghamdi ${ }^{1}$, Muath M. Alghamdi ${ }^{1}$, Hassan A. Alhassan ${ }^{1}$ and \\ Ahmad R. Bashnakli'. Mazen Doumani ${ }^{2}$ \\ 1. Internship dentists, Al-Farabi dental college, Riyadh, Saudi Arabia. \\ 2. MSc, Department of restorative dental sciences, Al-Farabi dental college, Riyadh, Saudi Arabia
}

\section{Manuscript Info}

\section{Manuscript History}

Received: 10 January 2019

Final Accepted: 12 February 2019

Published: March 2019

Key words:-

Attitudes, Modern endodontics, General practitioner, Root canal, Survey.

\begin{abstract}
The main goal of endodontic treatment procedure is to preserve normal periradicular tissue against spreading of infection (1). This is usually achieved by root canal treatment. Unfortunately, failure may occur after root canal treatment, In this study, we focused on attitude and techniques used in re-treatment cases by dentists in Saudi Arabia, a cross-sectional study conducted by using an A questionnaire was designed on the basis of previously published surveys of endodontists and general practitioners (GPs). answered by approximately 236 dentists. The response to the questionnaire by internship students was highest (120), followed by general practitioner (83) and the least number of specialists (33) Results showed an agreement between the most of dentist's answers about the factors makes them decide to retreat the endodontically treated teeth, except in consensus most of the specialists $(72.8 \%)$ that retreatment is mandatory when loss of coronal seal. More than $85 \%$ of practitioners are through with presence of some cases indicate referral to another dentist. Most of the specialists (55.2\%) referred to the reason for the absence of required tools and equipment. In most responses, there was a total agreement between all practitioners in different scientific degrees. The success of non-surgical root canal retreatment depends on many factors, such as case selection, years of experience, techniques, and materials used during the procedure.
\end{abstract}

Copy Right, IJAR, 2019,. All rights reserved.

\section{Introduction:-}

The main goal of endodontic treatment procedure is to preserve normal periradicular tissue against spreading of infection (1). This is usually achieved by root canal treatment. Unfortunately, failure may occur after root canal treatment ${ }^{(2,3)}$. This failure after initial treatment caused by persistent of microorganisms in the root canal system ${ }^{(4)}$. Streptococcus, Dialister, Fusobacterium, Filifactor have been detected in treated teeth. But the most frequently detected species in post-treatment diseases is Enterococcus faecalis according to several studies. So, the main aim of retreatment procedure is the removal of previous root filling material to allow for the disinfection and obturation of the root canal ${ }^{(5,6,7)}$. 
Removal of root filling materials requires more mechanical manipulations when compared with initial endodontic treatment. Different techniques used in retreatment procedures include; hand files or rotary instruments with or without heat, solvent, and/or ultrasonic instruments ${ }^{(8)}$.

In this study, we focused on attitude and techniques used in re-treatment cases by dentists in Saudi Arabia. Moreover, our survey based on collecting the information about the differences in treatment plan choices which may depend on educational background, years of clinical experiences, attitude of involved persons, and also clinical equipment.

\section{Materials and Methods:-}

A questionnaire was designed on the basis of previously published surveys of endodontists and general practitioners (GPs) ${ }^{(9,10,11,12)}$. It was submitted using a Google form and a hard copy to 236 active dentists and distributed to three categories of dentists (internship, GPs \& specialist).

All survey participants were asked to provide demographic information about gender, practice years and scientific degree $^{(13)}$. The other questions addressed, the percentage of weekly root canal re-treatment cases, the factors makes some cases must be re-treated ${ }^{(14)}$, causes of referral for some cases, techniques were mostly used during retreatment procedure, most common errors that have been detected during procedures, the use of intra- canal medicaments between visits, convenient time for cases follow up and the prognosis of most re-treated cases ${ }^{(15) .}$

\section{Results:-}

In a three-month period, the survey was answered by approximately 236 dentists. The response to the questionnaire by internship students was highest (120), followed by a general practitioner (83) and the least number of specialists (33). The first table included the basal characteristics of participants such as (distribution of participants by scientific degree, gender and years of experience). Generally, the male participants were the highest ratio (60.6\%) than female dentists (39.4\%). $45.5 \%$ of specialists have experience years over 15 years and the highest percentage of all participants. In the other side, $51.8 \%$ of general practitioner and $100 \%$ of internship students have less than 5 years of clinical experience who are considered the majority of participants in this questionnaire. (Table1)

When asking the practitioners on an average number of retreatment cases coming to clinic per week, we found that the majority of answers were less than $25 \%$. Results showed an agreement between the most of dentist's answers about the factors makes them decide to re-treat the endodontically treated teeth, except in consensus most of the specialists $(72.8 \%)$ that retreatment is mandatory when loss of coronal seal. More than $85 \%$ of practitioners are through with presence of some cases indicate referral to another dentist. Most of the specialists (55.2\%) referred to the reason for the absence of required tools and equipment. But results revealed the cause of the general dentist's referral was mainly when facing difficulties and complicated cases. (Table 2)

Table number three showed the results related to the behaviors and techniques used in retreatment procedure. Rotary files with solvent were the most used with specialists group (57.8\%).60\% General practitioners and 59.1\% internship adopted the manual files with a solvent in most cases. The usual errors that encountered during retreatment procedures were ledge and blockage at an average rate of 30-45\% with all practitioners. A high percentage of the responses (more than 65\%) were supported the use of intra-canal medication between visits. (Table 3) $60-67 \%$ of all practitioners preferred to follow up their cases from 3 to months to ensure the success of the retreatment procedure. The prognosis was fair for the most participant (52-63\%) and rated well in the range 30-33\% for the retreated cases. (Table 4)

Table1:-Basic information of practitioners

\begin{tabular}{|c|c|c|c|c|c|c|c|}
\hline \multicolumn{2}{|l|}{ Scientific degree } & \multicolumn{2}{|c|}{ Internship } & \multicolumn{2}{|c|}{ General practitioner } & \multicolumn{2}{|c|}{ Specialist } \\
\hline \multicolumn{2}{|l|}{ Total number } & \multicolumn{2}{|c|}{120} & \multicolumn{2}{|c|}{83} & \multicolumn{2}{|c|}{33} \\
\hline \multirow[t]{2}{*}{ Gender } & Male & \multicolumn{2}{|l|}{76} & \multicolumn{2}{|l|}{47} & \multicolumn{2}{|l|}{20} \\
\hline & Female & \multicolumn{2}{|l|}{44} & \multicolumn{2}{|l|}{36} & \multicolumn{2}{|l|}{13} \\
\hline \multirow{4}{*}{$\begin{array}{l}\text { Years of } \\
\text { Experience: }\end{array}$} & Years & Number & Percentage & Number & Percentage & Number & Percentage \\
\hline & $0-5$ & 120 & $100 \%$ & 43 & $51.8 \%$ & 3 & $9 \%$ \\
\hline & $6-10$ & 0 & 0 & 22 & $26.5 \%$ & 8 & $24.3 \%$ \\
\hline & $11-15$ & 0 & 0 & 10 & $12 \%$ & 7 & $21.2 \%$ \\
\hline
\end{tabular}




\begin{tabular}{|l|l|l|l|l|l|l|}
\hline More than 15 & 0 & 0 & 8 & $9.7 \%$ & 15 & $45.5 \%$ \\
\hline
\end{tabular}

Table 2:-Experience in case selection

\begin{tabular}{|c|c|c|c|c|c|c|c|}
\hline \multicolumn{2}{|l|}{ Scientific degree } & \multirow{2}{*}{\multicolumn{2}{|c|}{ Internship }} & \multirow{2}{*}{\multicolumn{2}{|c|}{$\begin{array}{l}\text { General } \\
\text { practitioner }\end{array}$}} & \multirow{2}{*}{\multicolumn{2}{|c|}{ Specialist }} \\
\hline Question & Options & & & & & & \\
\hline \multirow{5}{*}{$\begin{array}{l}\text { Percentage of cases } \\
\text { coming to the clinic } \\
\text { weekly and require root } \\
\text { canal re-treatment: }\end{array}$} & & Numb. & $\%$ & Numb. & $\%$ & Numb. & $\%$ \\
\hline & $1-25 \%$ & 80 & $66.7 \%$ & 43 & $51.8 \%$ & 14 & $42.4 \%$ \\
\hline & $26-50 \%$ & 36 & $30 \%$ & 26 & $31.3 \%$ & 9 & $27.3 \%$ \\
\hline & $51-75 \%$ & 4 & $3.3 \%$ & 14 & $16.9 \%$ & 3 & $9.1 \%$ \\
\hline & More than $75 \%$ & 0 & $0 \%$ & 0 & $0 \%$ & 7 & $21.2 \%$ \\
\hline \multirow{9}{*}{$\begin{array}{l}\text { Factors make/s you } \\
\text { decide to re-treat the } \\
\text { endodontically treated } \\
\text { teeth? ( you can select } \\
\text { more than one) }\end{array}$} & & Numb. & $\%$ & Numb. & $\%$ & Numb. & $\%$ \\
\hline & $\begin{array}{l}\text { When replacing fillings, } \\
\text { posts, and crowns with } \\
\text { symptomless teeth. }\end{array}$ & 24 & $20 \%$ & 14 & $11.6 \%$ & 12 & $36.4 \%$ \\
\hline & $\begin{array}{l}\text { Presence of symptomatic } \\
\text { periapical lesion. }\end{array}$ & 97 & $80.1 \%$ & 64 & $77.1 \%$ & 33 & $100 \%$ \\
\hline & $\begin{array}{l}\text { Presence of asymptomatic } \\
\text { periapical lesion. }\end{array}$ & 56 & $46.6 \%$ & 38 & $45.8 \%$ & 21 & $63.6 \%$ \\
\hline & $\begin{array}{l}\text { Poor quality of obturation } \\
\text { without periapical lesion. }\end{array}$ & 55 & $45.8 \%$ & 36 & $43.4 \%$ & 18 & $54.5 \%$ \\
\hline & $\begin{array}{l}\text { All old obturations should } \\
\text { be re-treated. }\end{array}$ & 5 & $4.1 \%$ & 6 & $7.2 \%$ & 5 & $15.1 \%$ \\
\hline & Presence of broken files. & 15 & $12.5 \%$ & 10 & $12 \%$ & 7 & $21.2 \%$ \\
\hline & Loss of coronal seal. & 47 & $39.2 \%$ & 25 & $30.2 \%$ & 24 & $72.8 \%$ \\
\hline & $\begin{array}{l}\text { Probability of presence } \\
\text { missing canals. }\end{array}$ & 75 & $62.5 \%$ & 48 & $57.8 \%$ & 23 & $69.7 \%$ \\
\hline \multirow{3}{*}{$\begin{array}{l}\text { If any retreatment cases } \\
\text { indicated for a referral? }\end{array}$} & & Numb. & $\%$ & Numb. & $\%$ & Numb. & $\%$ \\
\hline & Yes & 117 & $97.5 \%$ & 71 & $85.5 \%$ & 29 & $87.9 \%$ \\
\hline & No & 3 & $2.5 \%$ & 12 & $14.5 \%$ & 4 & $12.1 \%$ \\
\hline \multirow{5}{*}{$\begin{array}{l}\text { The cause of the referral? } \\
\text { (if answer YES to the } \\
\text { previous question) }\end{array}$} & & Numb. & $\%$ & Numb. & $\%$ & Numb. & $\%$ \\
\hline & $\begin{array}{l}\text { Absence of required tools } \\
\text { and equipment. }\end{array}$ & 33 & $28.2 \%$ & 16 & $22.5 \%$ & 16 & $55.2 \%$ \\
\hline & Lack of skills. & 39 & $33.3 \%$ & 10 & $14 \%$ & 5 & $17.3 \%$ \\
\hline & Complicated cases. & 40 & $34.2 \%$ & 45 & $63.5 \%$ & 8 & $27.5 \%$ \\
\hline & Knowledge & 5 & $4.3 \%$ & 0 & $0 \%$ & 0 & $0 \%$ \\
\hline
\end{tabular}

Table 3:-Behaviors and techniques during retreatment procedure

\begin{tabular}{|c|c|c|c|c|c|c|c|}
\hline \multicolumn{2}{|l|}{ Scientific degree } & \multirow{2}{*}{\multicolumn{2}{|c|}{ Internship }} & \multirow{2}{*}{\multicolumn{2}{|c|}{$\begin{array}{l}\text { General } \\
\text { practitioner }\end{array}$}} & \multirow{2}{*}{\multicolumn{2}{|c|}{ Specialist }} \\
\hline \multirow{3}{*}{$\begin{array}{l}\text { Question } \\
\text { The most common } \\
\text { techniques or tools used } \\
\text { in retreatment cases? }\end{array}$} & \multirow[t]{2}{*}{ Options } & & & & & & \\
\hline & & Numb. & $\%$ & Numb. & $\%$ & Numb. & $\%$ \\
\hline & $\begin{array}{l}\text { Manual files (H-files, K- } \\
\text { files) with solvent. }\end{array}$ & 72 & $60 \%$ & 49 & $59.1 \%$ & 6 & $18.2 \%$ \\
\hline & $\begin{array}{l}\text { Manual files (H-files, K- } \\
\text { files) without solvent. }\end{array}$ & 37 & $30.8 \%$ & 7 & $8.4 \%$ & 2 & $6 \%$ \\
\hline & Rotary files with solvent. & 8 & $6.7 \%$ & 20 & $24.1 \%$ & 19 & $57.6 \%$ \\
\hline & Rotary files without solvent. & 3 & $2.5 \%$ & 7 & $8.4 \%$ & 6 & $18.2 \%$ \\
\hline A most common problem & & Numb. & $\%$ & Numb. & $\%$ & Numb. & $\%$ \\
\hline encountered during & Apical transportation & 8 & $6.7 \%$ & 8 & $9.6 \%$ & 3 & $9.1 \%$ \\
\hline retreatment procedures. & Broken instruments & 8 & $6.7 \%$ & 16 & $19.3 \%$ & 3 & $9.1 \%$ \\
\hline & Ledge formation & 41 & $34.2 \%$ & 21 & $25.3 \%$ & 10 & $30.3 \%$ \\
\hline & Perforation & 19 & $15.8 \%$ & 7 & $8.4 \%$ & 2 & $6 \%$ \\
\hline & Blockage & 44 & $36.6 \%$ & 31 & $37.4 \%$ & 15 & $45.5 \%$ \\
\hline If prefer to & & Numb. & $\%$ & Numb. & $\%$ & Numb. & $\%$ \\
\hline
\end{tabular}




\begin{tabular}{|l|l|l|l|l|l|l|l|}
\hline \multirow{2}{*}{$\begin{array}{l}\text { canal medicaments } \\
\text { between visits? }\end{array}$} & Yes & 88 & $73.3 \%$ & 53 & $63.8 \%$ & 23 & $69.7 \%$ \\
\cline { 2 - 8 } & No & 32 & $26.7 \%$ & 30 & $36.2 \%$ & 10 & $30.3 \%$ \\
\hline
\end{tabular}

Table 4:-Follow up and the Expected prognosis after retreatment procedure

\begin{tabular}{|c|c|c|c|c|c|c|c|}
\hline \multicolumn{2}{|l|}{ Scientific degree } & \multirow{2}{*}{\multicolumn{2}{|c|}{ Internship }} & \multirow{2}{*}{\multicolumn{2}{|c|}{$\begin{array}{l}\text { General } \\
\text { practitioner }\end{array}$}} & \multirow{2}{*}{\multicolumn{2}{|c|}{ Specialist }} \\
\hline \multirow{6}{*}{$\begin{array}{l}\text { Question } \\
\text { After finishing of } \\
\text { retreatment, what is the } \\
\text { proper time to follow up } \\
\text { the retreated tooth? }\end{array}$} & Options & & & & & & \\
\hline & & Numb. & $\%$ & Numb. & $\%$ & Numb. & $\%$ \\
\hline & From 1 week to 1 month & 37 & $30.8 \%$ & 16 & $19.4 \%$ & 8 & $24.2 \%$ \\
\hline & 3 months to 6 months & 72 & $60 \%$ & 56 & $67.6 \%$ & 22 & $66.7 \%$ \\
\hline & More than 6 months & 11 & $9.2 \%$ & 9 & $10.5 \%$ & 3 & $9.1 \%$ \\
\hline & No need for follow up & 0 & $0 \%$ & 2 & $2.5 \%$ & 0 & $0 \%$ \\
\hline \multirow{4}{*}{$\begin{array}{l}\text { What is the prognosis of } \\
\text { most retreatment cases? }\end{array}$} & & Numb. & $\%$ & Numb. & $\%$ & Numb. & $\%$ \\
\hline & Poor & 18 & $15 \%$ & 11 & $13.3 \%$ & 2 & $6 \%$ \\
\hline & Fair & 63 & $52.5 \%$ & 44 & $53 \%$ & 21 & $63.7 \%$ \\
\hline & Good & 39 & $32.5 \%$ & 28 & 33.7 & 10 & $30.3 \%$ \\
\hline
\end{tabular}

\section{Discussion:-}

Post-treatment disease may persist our emerge because of persistent bacteria in the root canal system as a consequence of insufficient cleaning, untreated canals, inadequate filling or coronal leakage. Non-surgical root canal retreatment is often indicated as a first choice to eliminate or reduce the microbial infection ${ }^{(16,17)}$.

According to the collected information from the practitioners about the cases coming to the clinic per week and require root canal retreatment, the answers revealed only $1-25 \%$ overall the endodontic cases. Therefore this is referred to as the generally good quality of root canal treatment ${ }^{(18)}$. Many factors were reported by internship, general practitioners and specialists that should be considered before making their decisions to retreat endodontically treated teeth ${ }^{(19)}$. Presence of symptomatic periapical lesion may be associated with poor quality of obturation or probability of presence missed canals, so this is represented an indication for root canal retreatment depending on our results and previously studied intention to avoid the progression of the lesion and to lower the possibility of future complications ${ }^{(20,21)}$. In addition, the specialists were agreed with many researchers who concluded that "the quality of the coronal restoration is significantly more important than the quality of the endodontic treatment for periapical health.". Moreover, the post-endodontic restoration was considered as a requirement only for restoring the tooth to function. The fact that it could affect the outcome of endodontic treatment $(22,23)$.

The results showed that more than $85 \%$ of all participants preferred to refer the retreatment cases for different reasons. The reasons were evenly distributed between complicated cases, lack of skills and absence of required tools and equipment regarding internship, while the general practitioner prioritizes to refer the complicated cases. Lack of tools and equipment was the main issue for specialists.

The degree of root canal cleanliness and hence the amount of remaining filling material after gutta-percha removal might be affected by several factors; including the technique and instruments used for removal, the adjunctive use of a solvent, type of filling material and the root canal anatomy ${ }^{(24)}$. In the current study, most of the specialists preferred to use rotary files in combination with a solvent (57.6\%), this may be to benefit from its features such as preserve the working time and its effectiveness in the retreatment cases ${ }^{(25,26)}$. On the other hand, most of the internship and general practitioner dentist used manual files (H-files, K-files) with solvent.

Failure to understand the rationale behind cleaning and shaping concepts can increase the occurrence of needless complications such as blockages, ledge formation, apical transportation, and perforations ${ }^{(27)}$. The presence of a ledge, blockage, broken instruments and perforation may result in incomplete instrumentation and disinfection of the root canal system as well as the incomplete filling of the canal. Consequently, there might be a causal relationship between this errors formation and unfavorable endodontic treatment outcomes ${ }^{(28,29,30)}$. Ledges and blockage were the highly rated procedural accident had been encountered during endodontic retreatment for most of the practitioners. Apical transportation, broken instrument, and perforation can happen also, but at a very low rate as the resulting score ${ }^{(31)}$. 
Many studies suggested the use of intra- canal medication between visits to exert their effects as a disinfectant and to promote healing to the periapical area ${ }^{(32,33)}$. Gomes et al. ${ }^{(34)}$ observed that $2 \%$ of chlorhexidine $(\mathrm{CHX})$ showed the maximum zone of inhibition against Porphyromonasgingivalis, Enterococcus faecalis, Actinomycesviscosus, and Candida albicans followed by a combination of calcium hydroxide $(\mathrm{Ca}(\mathrm{OH}) 2)$ and $\mathrm{CHX}$ and the least with $\mathrm{Ca}(\mathrm{OH}) 2$ alone. It is generally accepted by most participants to use intra-canal medicaments (more than $60 \%)$ to achieve better prognosis after finishing the procedure ${ }^{(35)}$.

The majority of studies noted the presence of apical periodontitis as an indication for retreatment; most reported a negative influence of apical periodontitis on the success of nonsurgical retreatment. These studies demonstrated a reduction in the success of $13 \%-36 \%^{(36,37,38)}$. The size of the apical lesion might also have a deleterious effect on outcomes for endodontic surgery, with larger lesions being related to less favorable healing. Preexisting procedural accidents also have a negative effect on healing. Gorni and Gagliani ${ }^{(39)}$ examined the influence of alterations in the root canal morphology during previous treatment such as transportations and lodging. They found a $40 \%$ drop in nonsurgical retreatment success when there was a preexisting alteration in the morphology compared with teeth in which the canal morphology was respected. The presence of perforation results in a $31 \%$ decrease in success. Therefore, due to the presence of these factors, most of all participants found the prognosis of retreated cases is fair. The main goal of retreatment procedures is to eliminate inflammation or infection from and maintain tooth functions. Accordingly, it is important to follow up the retreated tooth to ensure the success of the procedure. Most of the responses recommend that 3 to 6 months of follow up is enough. Length of follow-up time affects the outcome, Frank AL et al. ${ }^{(40)}$ and Rud J et al. ${ }^{(41)}$ claimed that 1 year follow-up periods might be insufficient to predict long-term healing, particularly for cases with preoperative lesions or when the healing is uncertain at 1 year. Based on that; selection length time from three to six months to follow the cases is only enough to make sure that the initial success is done.

\section{Conclusion:-}

In most responses, there was a total agreement between all practitioners in different scientific degrees. The success of non-surgical root canal retreatment depends on many factors, such as case selection, years of experience, techniques, and materials used during the procedure.

\section{References:-}

1. Keleş A, Şimşek N, Alçin H, Ahmetoglu F, Yologlu S. Retreatment of flat-oval root canals with a self-adjusting file: An SEM study . Dent Mater J. 2014;33(6):786-91.

2. Torabinejad M, Corr R, Handysides R, Shabahang S. Outcomes of nonsurgical retreatment and endodontic surgery: a systematic review. J Endod 2009; 35: 930-937 .

3. deChevignyC,DaoTT,BasraniBR,MarquisV,FarzanehM, Abitbol S, Friedman S. Treatment outcome in endodontics: the Toronto study_-phase 4: initial treatment. J Endod 2008; 34: 258-263 .

4. Isabela N. Rôças and José F. Siqueira, Jr. Characterization of Microbiota of Root Canal-Treated Teeth with PosttreatmentDisease .J ClinMicrobiol. 2012 May; 50(5): 1721-1724

5. Gomes BP, Pinheiro ET, Jacinto RC, Zaia AA, Ferraz CC, Souza-Filho FJ.Microbial analysis of canals of root-filled teeth with periapical lesions using polymerase chain reaction. J Endod. 2008 May;34(5):537-40.

6. Molander A , Reit C, Dahlén G, Kvist T. Microbiological status of root-filled teeth with apical periodontitis. Int Endod J. 1998 Jan;31(1):1-7.

7. Pinheiro ET, Gomes BP, Ferraz CC, Sousa EL, Teixeira FB, Souza-Filho FJ.Microorganisms from canals of rootfilled teeth with periapical lesions. Int Endod J. 2003 Jan;36(1):1-11.

8. Topçuoğlu HS, Demirbuga S, Tuncay Ö, Pala K, Arslan H, Karataş E .The Effects of Mtwo, R-Endo, and D-RaCe Retreatment Instruments on the Incidence of Dentinal Defects during the Removal of Root Canal Filling Material .J Endod. 2014 Feb;40(2):266-70

9. Bangerter C, Mines P, Sweet M. The use of intraosseous anesthesia among endodontists: results of a questionnaire. J Endod 2009;35:15-18.

10. Kersten DD, Mines P, Sweet M. Use of the microscope in endodontics: results of a questionnaire. J Endod 2008;34:804-7

11. Chan AW, Low D, Cheung GS, Ng RP. Questionnaires survey of endodontic practice profile among dentists in Hong Kong. Hong Kong Dent J 2006;3:80-87

12. Whitworth JM, Seccombe GV, Shoker K, Steele JG. Use of rubber dam and irrigant selection in UK general dental practice.IntEndod J. 2000 Sep;33(5):435-41.

13. Pagonis TC, Fong CD, Hasselgren G. Retreatment decisions: a comparison between general practitioners and endodontic postgraduate. J Endod. 2000 Apr;26(4):240-1 
14. Sjogren U, Hagglund B, Sundqvist G, Wing K.. Factors affecting the long-term results of endodontic treatment. J Endod. 1990 Oct;16(10):498-504

15. Engström B, Lundberg M. Correlation of positive cultures with the prognosis for canal re-treatment. Odontol Revy. 1965;16(3):193-203.

16. Rôças IN, Siqueira JF Jr. Characterization of microbiota of root canal-treated teeth with posttreatment disease.J ClinMicrobiol. 2012 May;50(5):1721-4. doi: 10.1128/JCM.00531-12. Epub 2012 Mar 7.

17. Imura N, Kato AS, Hata GI, Uemura M, Toda T, Weine F. A comparison of the relative efficacies of four hand and rotary instrumentation techniques during endodontic retreatment. IntEndod J. 2000 Jul;33(4):361-6.

18. Schestatsky R, Dartora G, Felberg R, Spazzin AO, Sarkis-Onofre R, Bacchi A, Pereira GKR. Do endodontic retreatment techniques influence the fracture strength of endodontically treated teeth? A systematic review and meta-analysis.J MechBehav Biomed Mater. 2019 Feb;90:306-312.

19. Kvist T, Heden G, Reit C . Endodontic retreatment strategies used by general dental practitioners. Oral Surg Oral Med Oral Pathol Oral RadiolEndod. 2004 Apr;97(4):502-7.

20. Gilbert GH, Tilashalski KR, Litaker MS, McNeal SF, Boykin MJ, Kessler AW; DPBRN Collaborative Group.. Outcomes of root canal treatment in Dental PBRN practices .Tex Dent J. 2013 Apr;130(4):351-9.

21. Yu VS, Khin LW, Hsu CS, Yee R, Messer HH. Risk Score Algorithm for Treatment of Persistent Apical Periodontitis J Dent Res. 2014 Nov;93(11):1076-82.

22. Ray HA, Trope M. Periapical status of endodontically treated teeth in relation to the technical quality of the root filling and the coronal restoration. Int Endod J. 1995 Jan;28(1):12-8.

23. Sritharan A. Discuss that the coronal seal is more important than the apical seal for endodontic success. AustEndod J. 2002 Dec;28(3):112-5.

24. Zmener O, Pameijer CH, Banegas G. Retreatment efficacy of hand versus automated instrumentation in oval-shaped root canals: an ex vivo study. IntEndod J. 2006 Jul;39(7):521-6.

25. Wennberg A, Orstavik D. Evaluation of alternatives to chloroform in endodontic practice. Endod Dent Traumatol. 1989 Oct;5(5):234-7.

26. Masiero AV, Barletta FB. Effectiveness of different techniques for removing gutta-percha during retreatment.IntEndod J. 2005 Jan;38(1):2-7.

27. Nagy CD, Bartha K, Bernath M, Verdes E, Szabo J. The effect of root canal morphology on canal shape following instrumentation using different techniques. IntEndod J 1997;30:133-40.

28. Kapalas A, Lambrianidis T. Factors associated with root canal ledging during instrumentation. Endod Dent Traumatol 2000;16:229-31

29. Harty FJ, Parkins BJ, Wengraf AM. Success rate in root canal therapy: a retrospective study of conventional cases. Br Dent J 1970;128:65-70.

30. Namazikhah MS, Mokhlis HR, Alasmakh K. Comparison between a hand stainlesssteel K file and a rotary NiTi 0.04 taper. J Calif Dent Assoc 2000;28:421-6.

31. Tabassum S, Khan FR. Failure of endodontic treatment: The usual suspects.Eur J Dent. 2016 Jan-Mar;10(1):144-7. doi: 10.4103/1305-7456.175682.

32. Madarati AA, Zafar MS, Sammani AMN, Mandorah AO, Bani-Younes HA. Preference and usage of intracanal medications during endodontic treatment .Saudi Med J. 2017 Jul;38(7):755-763. doi: 10.15537/smj.2017.7.18345.

33. Sathorn C, Parashos P, Messer H.Antibacterial efficacy of calcium hydroxide intracanal dressing: a systematic review and meta-analysis .IntEndod J. 2007 Jan;40 (1):2-10 .

34. Gomes BP, Montagner F, Berber VB, Zaia AA, Ferraz CC, de Almeida JF. Antimicrobial action of intracanal medicaments on the external root surface. J Dent 2009;37:76-81.

35. Barbosa CA1, Gonçalves RB, Siqueira JF Jr, De Uzeda M. Evaluation of the antibacterial activities of calcium hydroxide, chlorhexidine, and camphorated paramonochlorophenol as intracanal medicament. A clinical and laboratory study. J Endod. 1997 May;23(5):297-300.

36. de Chevigny C, Dao TT, Basrani BR. Treatment outcome in endodontics: the Toronto study-phases 3 and 4: orthograde retreatment. J Endod 2008;34:131-7.

37. Bergenholtz G, Lekholm U, Milthon R, Heden G, Odesjo B, Engstrom B. Retreatment of endodontic fillings. Scand J Dent Res 1979;87:217-24.

38. Sundqvist G, Figdor D, Persson S, Sjogren U. Microbiologic analysis of teeth with failed endodontic treatment and the outcome of conservative re-treatment. Oral Surg Oral Med Oral Pathol Oral RadiolEndod 1998;85:86-93.

39. Gorni FG, Gagliani MM. The outcome of endodontic retreatment: a 2-yr follow-up. J Endod 2004;30:1-4.

40. Frank AL, Glick DH, Patterson SS, Weine FS. Long-term evaluation of surgically placed amalgam fillings. J Endod 1992;18:391-8.

41. Rud J, Andreasen JO, Jensen JE. A follow-up study of 1,000 cases treated by endodontic surgery. Int J Oral Surg 1972;1:215-28. 